\title{
Türkiye'de Vesayetçi Paradigmanın Tasfiyesi Üzerine Dönemsel Bir Değerlendirme: 2002-2016
}

\author{
DOI: $10.26466 /$ opus. 835844
}

$*$

\author{
Ahmet Kizilkaya * \\ * Dr., T C. Millı̂ Eğitim Bakanlığı, Ankara/Türkiye \\ E-Posta: ahmetkizilkaya111@gmail.com \\ ORCID: $\underline{0000-0002-7275-3664}$ \\ Öz
}

Militarizm olgusu, Osmanlı geçmişinden devralınan modernleşme anlayışının bir uzantısı olarak Türk siyasal tarihini şekillendiren en önemli unsurlardan biri olmuştur. Cumhuriyetin kuruluş süreci ile sonrasinda yaşanan tek parti döneminde, militarist ideolojinin beslediği vesayetçi paradigma devlet düzeyinde kurumsallaşmış ve adeta sonraki yılların da kurucu referans değeri olarak işlev görmüş̧ür. Türkiye'nin 1945'ten beri süregelen demokrasi deneyimi, bu referans değerin taşıyıcısı konumunda bulunan ve kendisini devlet aygıtıyla özdeşleştiren vesayetçi azınlık ile söz konusu azınlı̆̆a karşı direnen ve geniş halk kitlelerinden oluşan sessiz çoğunluk arasındaki mücadelelerin seyri içinde gelişmiştir. 27 Mayıs'tan 15 Temmuz darbe girişimine dek uzanan tüm müdahale süreçleri, vesayetçi azınlı̆̆ın tahakkümcü otoritesinin sessiz çoğunluğun meşru iradesi karşısındaki yenilgisiyle sonuçlanmasına karşın, vesayetçi paradigma kendisini her seferinde yeniden üretebilme imkanını bulmuştur. Bu çalışmada, 2002-2016 yılların kapsayacak şekilde, Adalet ve Kalkınma Partisi'nin iktidarları döneminde yaşanan vesayetçi müdahaleler ile bunlarn tasfiyesine dönük mücadelelerin incelenmesi amaçlanmıştır. Bu amaca istinaden demokrasi, kriz ve askeri müdahale kavramları arasındaki ilişkisellik etraflıca tahlil edilmiştir.

Anahtar Kelimeler: Vesayetçi paradigma, darbe, AK Parti, demokrasi 


\title{
A Periodic Evaluation On The Elimination of Tutelary Paradigm in Turkey: 2002-2016.
}

\begin{abstract}
The militarism phenomenon, which is an extension of the modernization approach inherited from the Ottoman past, has been one of the most important elements that shaped Turkish political history. The tutelary paradigm, fed by the militarist ideology during the foundation process of the Republic and in the one-party period, has been institutionalized at the state level and served as the founding reference value also in the following years. Turkey's continual democratic experience since 1945, has developed in the course of the struggles between the tutelary minority who are the bearer of this reference value and identifies themselves with the state apparatus and the silent majority who consists of large mass of people and resists the minority. Although all the interventions ranging from May 27 to July 15 coup attempt resulted in defeat of the possessive authority of the tutelary minority against to legitimate will of the silent majority, the tutelary paradigm has found the opportunity to renew itself every time. In this study, it is aimed to examine tutelary interventions experienced during the rule of the Justice and Development Party and struggles for their liquidation covering the years 2002-2016. For this purpose, the relationality between the concepts of democracy, crisis and military intervention has been analyzed thoroughly.
\end{abstract}

Keywords: Tutelary paradigm, coup, The AK Party, democracy 


\section{Giriş}

Türkiye'nin çok partili hayata geçtiği 1945 yılından günümüze dek geçen süre, yalnızca kendisinin siyasal tarihi bakımından değil, aynı zamanda dünya siyasal tarihi açısından da özgün sayılabilecek birçok örneği muhtevidir. Ancak Türk siyasal tarihine verili bu örneklik durumu, Türkiye'nin ulusal gururunu okşayacak bir tarihsel mirasa ya da başkaları için emsal teşkil edecek bir gelişme/kalkınma/demokratikleşme modeline atıfta bulunan olumlu bir içeriğe değil, vesayetçi paradigmaların iğdiş ettiği antidemokratik bir geçmişe işaret etmektedir. Zira bu geçmiş, sık aralıklarla yapılan konvansiyonel nitelikli askeri darbeler ve/veya darbe teşebbüsleri, halkın özgür iradesiyle işbaşına gelmiş sivil siyasal iktidarları alaşağı etmeye dönük post-modern nitelikli müdahale girişimleri, e-muhtıralar, siyasal partilere yönelik kapatma davaları, kişi hak ve özgürlüklerini kısıtlayı$\mathrm{cl} /$ yasaklayıcı yasalar ve benzeri uygulamaların şekillendirdiği militarist bir iklim üretmiştir. Tabii bu iklimi üreten aktörler ve mekanizmalar, geniş toplumsal kesimlerin sessiz ve fakat istikrarlı direnci karşısında hep başarısızlığa uğramışlar, halkın iradesine rağmen ve ona karşı kurdukları vesayetçi yapıların sürdürülebilir olmasını sağlayamamışlardır. Bu yönüyle baktığımızda, Türkiye'nin demokrasi tarihini sessiz çoğunluk ile vesayetçi azınlık arasındaki diyalektik mücadelenin tarihi olarak okumak mümkündür. Yirminci yüzyılın ikinci yarısının neredeyse tamamını kuşatan ve genellikle sessiz çoğunluğun aleyhine olacak şekilde devam eden bu mücadele, yirmi birinci yüzyılın ilk yıllarından itibaren farklı bir şekilde seyretmiş; kendisini ülkenin gerçek sahibi olarak gören seçkinci zümrelerin oluşturduğu statüko/yerleşik düzen zayıflamaya ve halkın demokratik iradesini yansıtan aktör ve mekanizmalar öne çıkmaya başlamıştır. Bu süreçte, geçmişte yapılan askeri darbeler ve darbe teşebbüsleri sorgulanmaya, dahası yarg1lanmaya başlamış, siyasal ve hukuki düzenlemeler yoluyla özgürlük alanları genişletilmiş, başta yazılı ve görsel medya olmak üzere, tüm yaşam alanları ülkenin sahip olduğu çoğulculuğu yansıtacak şekilde çeşitlendirilmiştir. Fakat bütün bu olumlu değişimlere ve ülkenin gerek içeride gerekse dişarıda yakaladığ1 güçlü gelişme ivmesine rağmen, Türkiye'nin geçmiş yüzyıldan tevarüs ettiği olumsuz mirasın izleri, varlı̆̆ını açık ve/veya örtük bir biçimde sürdürmüştür. Zira on yıllar boyunca devam eden ve zaman içinde kurumsallaşan vesayetçi paradigma, kendisini her koşul ve şart altında ye- 
nileyebileceği zengin bir 'demokrasiye müdahale literatürü' üretmiştir. Türkiye'nin kısa süreli demokrasi tarihi, bu literatür uyarınca gerçekleşen veya akim kalan çok sayıda siyasal, askeri, bürokratik ve hukuki darbelerle ya da darbe teşebbüsleriyle doludur. Ancak yukarıda da belirtildiği üzere, bu darbe girişimleri, halkın orta-uzun vadede ve sağduyulu bir şekilde gösterdiği demokratik refleksler sayesinde atlatılmış ve ülkenin yörüngesi geri döndürülemez bir şekilde demokrasi rotasına oturtulmuştur (Kızılkaya, 2014, s. 54-55).

27 Mayıs 1960 Askeri Darbesi ile başlayan demokrasiye müdahale geleneğinin son ve en şedit örneğini oluşturan 15 Temmuz 2016 darbe girişimi karşısında sergilenen ve tüm toplumsal kesimlerin dahil olduğu kolektif direniş, gerek güncelliği gerekse spontane niteliği dolayısıyla, söz konusu refleksin ve demokrasiye sahip çıkma bilincinin ne denli kökleştiğini ve özümsendiğini açıkça ortaya koymuştur. Dünya tarihinde eşine ender rastlanılabilecek bu direniş, büyük bedeller ödeme pahasına da olsa, halkın, en genel ifadesiyle, demokrasiden ve demokratik kazanımlarından vazgeçmeyeceğini ve iradesini vesayet odaklarına teslim etmeyeceğini somut bir şekilde göstermiştir. Siyasal, toplumsal ve psikolojik etkileri ve sonuçları itibarıyla güncelliğini halen koruyan 15 Temmuz darbe girişimi ve bu girişim karşısında sergilenen kolektif direniş, Türk demokrasisinin geçmişten bu yana süregelen ve bulduğu her fursatta kendisini gösteren kriz üretme odakları ve araçlarından arındırılmasına ve yeniden yapılandırılmasına dönük ihtiyacı daha da belirginleştirmiştir. Nitekim 15 Temmuz'un akabinde, Türkiye, yönetim yapısını da içerecek şekilde köklü bir değişim sürecinin içine girmiş; klasik parlamenter sistemden vazgeçerek başkanlık sisteminin Türkiye'ye özgü versiyonu olarak addedilen Cumhurbaşkanlığı Hükümet Sistemine geçiş yapmıştır. 2018 yılının ikinci yarısından itibaren yürürlüğe giren ve halen yapılanma aşamasında olan bu sistem, Türk demokrasisinin sorunlu/vesayetçi doğasını düzeltip düzeltemeyeceği ya da darbe, muhtıra ve benzeri krizleri üretme potansiyelini kalıcı biçimde ve yapısal bir şekilde izale edip edemeyeceği yönündeki tartışmalardan ve oluşturduğu yönetim modeli ile uygulama sürecine ilişkin eleştirilerden bağımsız olarak, büyük oranda vesayetçi paradigmanın tasfiyesine dönük bir arayışın neticesinde şekillenmiştir.

Bu çalışmada, 15 Temmuz 2016 tarihinde gerçekleşen darbe girişimi ve sonuçları da dahil olmak üzere, Adalet ve Kalkınma Partisi'nin (AK Parti) 3 
Kasım 2002 seçimleri ile başlayan ve günümüze dek kesintisiz olarak devam eden iktidar(lar)1 boyunca süregelen vesayetçi müdahaleler ile bunların tasfiyesine dönük mücadelelerin incelenmesi amaçlanmıştır. Bu amaç doğrultusunda, ilk olarak, tarafımızca daha önce yayımlanan 'Türk Demokrasisinin Değişen Kriz Algısı' (Kızılkaya, 2013) başlıklı makalenin gözden geçirilmiş ve geliştirilmiş versiyonunu baz alacak şekilde demokrasi ve kriz kavramları arasındaki ilişkisellik sorgulanmıştır. Bu sorgulama kapsamında, öncelikle AK Parti'nin ilk on yıllık dönemi boyunca gerçekleşen ve vesayetçi paradigmanın tasfiyesini hedefleyen süreç analiz edilmiş; akabinde de Türk demokrasisinin değişen kriz algısı irdelenmiştir. Bunu takip eden bölümde ise, vesayetin yeni bir türü olarak beliren Fetö yapılanması 15 Temmuz darbe girişimi ve sonuçları bağlamında ele alınmış; ardından da 2002 ile 2016 yıllarını kapsayacak şekilde vesayetçi paradigmanın tasfiyesine yönelik mücadelelerin genel bir değerlendirmesi yapılmıştır.

\section{Vesayetçi Paradigmanın Tasfiyesi Yönündeki Çabalar Işı̆̆ında AK Parti'nin İlk On Yılı}

Demokrasi ve kriz kavramları arasındaki ilişkisellik sorgulandığında, akla ilk olarak askeri müdahaleler gelmektedir. Hele Türkiye gibi, yarım yüzyılı aşkın demokrasi tarihi boyunca çok sayıda askeri müdahaleye tanıklık etmiş ve bu müdahalelerin biçimlendirdiği bir siyasal, hukuksal ve toplumsal düzen içinde yaşamak zorunda kalmış ülkelerde, kriz sözcügünün demokrasi bağlamında yarattı̆̆ çağrışımın 'askeri darbe' ya da 'müdahale' tanımının dışına çıkması pek mümkün görünmemektedir.

Ancak demokrasi ve kriz kavramları arasındaki ilişkiselliği yalnızca ve doğrudan askeri darbelerle sınırlı tutmak da doğru bir yaklaşım değildir. Zira olağan siyasal süreçlere özgü demokratik ilke, kural, tutum ve teamüllerin ihlal edilmesine, askıya alınmasına ya da ortadan kaldırılmasına neden olan veya buna zemin oluşturan 'sivil' nitelikli başka dinamikler de bulunmaktadır. Türkiye'nin yakın dönem siyasal tarihi incelendiğinde, demokratik düzenin doğrudan veya dolaylı olarak krize girmesine ya da en azından zayıflamasına yol açan çok sayıda 'sivil' nitelikli örnek bulmak mümkündür. Bu bağlamda, post-modern bir darbe olarak nitelendirilen 28 Şubat sürecine giden yolda merkez medya organlarının attığı anti-demokratik 
manşetler ${ }^{1}$, yine bu dönemde vuku bulan ve işvereninden sendikacısına dek birçok kesimi bir araya getiren '5'li çete' ${ }^{2}$ ve aynı minvaldeki yapılar, evrensel düzeyde kabul görmüş temel hak ve özgürlükleri yasaklayan/yasaklamaya çalışan sivil iktidarlar, siyasal partiler ve siyasetçiler, ‘halkın oylarıyla seçilmiş ve onun iradesini yansitan demokratik iktidarlara karşı' darbe çağrısı yapan üniversite rektörleri, 2007 yılında Cumhurbaşkanlığı seçimleri dolayısıyla yaşanan 367 krizi ve benzeri birçok örnekten bahsedilebilir.

Şüphesiz ki, bu örneklerin hiçbirini askeri müdahalelerin kurumsallaştırdığı devlet ve toplum düzeninden bağımsız olarak ele almak mümkün değildir. Hatta bu ve benzeri örneklerin, ya bir önceki darbenin kazanımlarını korumak ya da olası bir darbenin zeminini hazırlamak adına sahneye konulduğunu söylemek de abartı olmayacaktır. Bu yönüyle ele alındığında, askeri vesayetin yalnızca sivil siyaset alanını değil, ekonomiden eğitime, medyadan işçi-işveren sendikalarına dek uzanan birçok alanı derinden etkilediği ve farklı saiklerle de olsa, bu alanların bazı aktörleri tarafından içselleştirildiğini açıkça ortaya koymaktadır.

Esasında bu durum, Türkiye'deki demokrasi krizinin gerçekte neye tekabül ettiğini de bütün açıklığıyla gözler önüne sermektedir. Türkiye'de demokrasinin istenilen düzeyde kurumsallaşamamasının ya da yerleşememesinin en büyük müsebbibi, sık aralıklarla yapılan askeri müdahaleler kadar, bu müdahalelerin oluşturduğu vesayetçi yapılar ve/veya bu yapılarla aynı paralelde hareket eden 'siviller' ve 'sivil kurumlar' dır. Bir başka ifadeyle söylendiğinde, askeri müdahaleler, her ne kadar Türk demokrasisi açısından onulmaz yaralar açmış olsa da, bu yaraların sürekliliğini sağlayan temel güç(ler), hep söz konusu müdahalelerin öncülü ya/ya da ardılı olan sivil dinamiklerden teşekkül etmiştir. Bu hususu, vesayetçi paradigmanın kökenini oluşturan militarist ideoloji ile ona yığınlar halinde destek veren sivil taşıyıcılar arasındaki zihniyet örtüşmesinin (Mahçupyan, 2013, s. 75) bir sonucu olarak değerlendirmek mümkündür. Nitekim 28 Şubat post-modern

\footnotetext{
1 Söz konusu dönemde merkez medya organlarında yer alan bazı manşetler şu şekildedir: "Ordu Rahatsız"- Sabah Gazetesi, 13.12.1996; "Laiklik Uyarısı"- Milliyet Gazetesi, 17.10.1996; "Bu Defa İsii Silahsız Kuvvetler Halletsin"- Hürriyet Gazetesi, 20.12.1996.

${ }^{2}$ 5'li çete vurgusu, 28 Şubat sürecinde iş dünyasının önemli kuruluşları arasında yer alan TüRK-iŞ, DiSK, TOBB, TiSK ve TESK'in bir araya gelmesiyle oluşturulan 'sivil inisiyatif' grubunu tanımlayan bir yakıştırma olup, bu grubun dönemin meşru iktidarını devirmeye yönelik cuntacı faaliyetlere verdiği açık ve yoğun desteğe atfen kullanılmaktadır.
} 
darbesi bu örtüşmenin sivil siyaset alanında karşıllk ve destek bulduğu bir dönemi temsil etmektedir. Söz konusu dönemde, vesayetçi paradigma, yalnızca silah gücüne ve mevzuat desteğine dayanmamış, aynı zamanda medya üzerinden kamuoyunu seferber eden ve geniş toplumsal kesimler nezdinde meşruiyet arayan bir girişim olarak temayüz etmiştir (Bayramoğlu, 2013, s. 55).

Kuşkusuz ki, demokrasi ve militarizm ile demokrasi ve kriz kavramları arasındaki ilişkiselliğin kendisini en somut şekilde açı̆̆a vurduğu zeminler askeri müdahale dönemleridir. Ancak yukarıdaki örneklerin de gösterdiği üzere, Türk demokrasi tarihi, militarizmin sadece sivil siyaset alanındaki kaba hegemonyasını değil, aynı zamanda siyasal, toplumsal ve ekonomik gelişmenin itici gücü olması gereken temel kurum ve aktörlerin bilinci üzerindeki tahakkümünü de ortaya koyan bir geçmişe sahiptir. 20. yüzyılın ikinci yarısından 21. yüzyılın başlarına kadar devam eden ve neredeyse 'istikrarm istisna, kriz ve kaosların ise kural' haline geldiği yarım asırlık dönem, bu geçmişin acı hatıralarıyla doludur.

Ancak sorunlu demokrasi tarihinin içerdiği bu acı hatıraların birbirine karşıt iki yönelimi beslediği ve bunun da 21. yüzyıl Türkiye'sinin temel siyasasını belirlediği söylenebilir. Zira neredeyse her on yılda bir tekrar eden askeri darbe ve muhtıralar ile 'sivil müdahaleler', bir taraftan Türkiye'nin evrensel standartlara uygun bir demokratik rejime kavuşmasını olanaksız kılarken; diğer taraftan da geniş halk kitlelerinin demokrasiye olan ilgi ve arzusunu artırmıştır. Türkiye'nin artık yapısal bir karakter kazanan demokrasi krizleri, zamanla adeta didaktik bir araca dönüşmüş ve bu kavramın içerdiği erdemlerin bir bütün olarak ve samimi bir şekilde sahiplenilmesine imkan sağlamıştır. Bir başka deyişle, yaşanan her demokrasi krizi ideal bir demokrasiye ulaşmanın aracı haline gelmiş ya da en azından bu doğrultuda işlev görmüştür.

Türkiye'nin geçtiğimiz yüzyıl içinde yaşadığı ve sonuçları açısından son derece tahrip edici olan 28 Şubat post-modern darbesinin şekillendirdiği anti-demokratik bir siyasal iklime rağmen, AK Parti'nin 3 Kasım 2002 seçimlerinde tek başına iktidara gelmesini de bu minvalde değerlendirmek mümkündür. Uzun süren vesayet yıllarına, Cumhuriyet tarihinin en büyük ekonomik krizi olan 2001 krizi de eklenince, yalnızca üçlü koalisyona dayalı siyasal iktidarın geleceği değil, aynı zamanda bir bütün olarak ülkenin akıbeti tehlikeye girmiş ve ciddi bir bunalım dönemi yaşanmıştır. Siyasal ve 
ekonomik istikrarın kaybolduğu, toplumsal barışın bozulmaya başladığı, Türkiye'nin hem bölgesel hem küresel düzeyde ciddi bir itibar kaybı yaşadığı bu dönemde, Türk demokrasisinin imdadına 3 Kasım 2002 erken genel seçimleri yetişmiş ve halkın özgür tercihleri sonucunda demokrasi yeniden rayına oturmaya başlamıştır.

Bu seçimlerden sonra Türkiye görece istikrarlı bir döneme kavuşmuş ve tek parti yönetimi altında siyasal, ekonomik, toplumsal, kültürel düzeylerde etkili olan çok yönlü bir değişim ve reform sürecine girmiştir. Tabii bunda, 1987 yılından bu yana süregelen ve fakat insan hakları alanındaki kötü sicili ile siyasal çoğulculuğu engelleyen mekanizmaların varlı̆̆ 1 dolayısıyla nihayete erdiremediği Avrupa Birliği'ne (AB) tam üyelik müzakerelerine 17 Aralık 2004'te başlama hakkını kazanmış olmasının (Şahin, 2006, s. 122) büyük bir payı vardır. $A B$ tam üyelik sürecinin de etkisiyle son derece önemli demokratik reformları gerçekleştiren Türkiye'nin bu dönemde gerek iç gerekse dış politik alanda yakaladığı nispeten güçlü siyasal ve ekonomik istikrar sayesinde, Türk demokrasisinin geçmiş yüzyıldan tevarüs ettiği vesayetçi paradigma ile ciddi bir hesaplaşma içine girilmiş ve Cumhuriyet tarihi boyunca ilk defa askeri darbeler, darbe teşebbüsleri, çete-mafya ve benzeri suç örgütleri sivil mahkemeler önünde yargılanmaya başlamıştır. AK Parti'nin ikinci dönemini içeren 2007-2011 yılları arasında ise vesayetçi paradigmanın askeri ve yargısal bürokrasi içindeki tasfiye süreci büyük oranda tamamlanmıştır (Şahin, 2013, s. 166).

Böylece 19. yüzyılın ilk çeyreğinden itibaren başladığı varsayılan Osmanlı-Türk modernleşmesinin bir süreklilik ilişkisi içinde günümüze kadar devam eden gelişmesi, belki de ilk defa bu denli radikal ve halk iradesine dayalı şekilde ilerleme imkanı bulmuştur. Gerçekten de, AK Parti'nin iktidarı altında geçen ilk on yıllık dönemde, geleneksel siyasal elitler tasfiye olmaya yüz tutmuş, vesayete dayalı yapılar çökertilmiş ve sistemsel düzeyde yaşanan değişimler sayesinde ülke gerçek bir demokratik hukuk devletine doğru evrilmeye başlamıştır. Bu süreçte, Türkiye'deki yerleşik statünün bozulmasından ve özgürlükçü eğilimlerin gelişmesinden rahatsız olan kişi, grup, kurum ve yapılar, öteden beri alışageldikleri yöntemleri ya da yenilerini kullanarak meşru ve sivil hükümeti alaşağı etmeye yönelik birçok girişimde bulunmuştur. Genelkurmay Başkanlığı'nın resmi internet sitesi aracllığıyla yayımladığı ve tarihe '27 Nisan e-muhtırası' olarak geçen bildiri, bu yöndeki girişimlerin en önemlisi olarak dikkat çekmiştir. Söz konusu bildiri, 
her ne kadar askeri vesayetin internet çağına uyarlanmış versiyonu olarak yöntemsel bir yenilik taşısa da, içeriği-dili ve amacı itibarıyla klasik vesayetçi paradigmanın tüm özelliklerini içinde barındırmıştır. AK Partili bir ismin cumhurbaşkanı olarak seçilmesini engellemeye dönük olarak hazırlanan 27 Nisan e-muhtırasına karşı dönemin hükümeti manifesto niteliğinde bir yanit vermiş ve Türk siyasal tarihi bakımından ilk olma özelliğini gösteren kararlı bir duruşla demokrasiye sahip çıkmıştır. E-muhtıradan yaklaşık üç ay sonra gerçekleşen 22 Temmuz 2007 seçimlerinin sonuçları, hükümetin bu duruşunun halk nazarında da büyük bir karşılık gördüğünü ortaya koymuş ve AK Parti daha büyük bir oy oranıyla yeniden iktidar olmuştur.

Bu dönemde, 27 Nisan e-muhtırası ile eş zamanlı olarak ve aynı amaca istinaden gerçekleşen Cumhuriyet Mitinglerinden iç karışıklık yaratma çabalarına, 2008-2012 yılları arasında küresel düzeyde yaşanan ekonomik krizin mümkün olan en güçlü şekilde Türkiye'ye yansıması için yapılan spekülasyonlardan çeşitli medya organları yoluyla halkı provoke etme gayretlerine kadar, Türk demokrasisinin kendisine karşı artık bağışıklık kazandığı her türlü konvansiyonel müdahale araçlarını kullanarak meşru iktidarı bertaraf etmenin yolları aranmıştır. Ancak bütün bu gelişmelere rağmen, gerek iktidarın kararlı duruşu gerekse geniş toplumsal kesimlerin, uzun gayretler sonucunda yakalanan siyasal ve ekonomik istikrara sahip çıkması sayesinde, bu türden konvansiyonel müdahale araçları geçmişte ifa ettikleri rolleri oynayamamıştır.

\section{Türk Demokrasisinin Değişen Kriz Algısı ve Yeni Vesayet Odaklarının Belirmesi}

AK Parti'nin ilk on yıllık döneminde Türk siyasasının temel yönelimleri ve işleyişi açısından yaşanan paradigmatik nitelikli değişim, Türk demokrasisinin kriz algısının da değişmesini sağlamıştır. Bu dönemde, hem Türk demokrasisinin duyarlılık gösterdiği faktörlerin kendisinde hem de bu faktörlere yönelik siyasal ve toplumsal duyarlılık düzeyinde ciddi bir değişim yaşanmıştır. Geçmiş yıllarda telaffuz edilmesi dahi demokratik işleyişin aksamasına neden olan/olabilen birçok faktör, artık ortalama bir Türk vatandaşının algı dünyasının dışına çıkmaya başlamıştır. Nitekim o dönemde tedavüle sokulan ve 'belirlenmiş bazı kırmızı çizgilerin' dışına taştığı ya da 'haddini aştığı' düşünülen meşru sivil iktidarlara yönelik olarak kullanılan 
konvansiyonel müdahale araçlarının neredeyse bütünüyle işlevsiz kalması da bundan kaynaklanmıştır.

Ancak vurgulamak gerekir ki, Türk demokrasisinin kriz algısındaki ve kriz odaklarına yönelik duyarlılığındaki bu değişim, demokratik düzenin tüm müdahale araçlarından arındığı/arındırıldığı anlamında kullanılmamaktadır. Nitekim AK Parti'nin üçüncü dönemi (2011-2015) ve sonrasında meydana gelen gelişmeler, gerek eski vesayet odaklarının etkinliğinin bir biçimde sürdügünü gerekse yeni vesayet odaklarının oluştuğunu ortaya koymuştur. Böylece siyasal iktidara ve bu iktidarın liderliğinde devam eden demokratikleşme-sivilleşme sürecine muhtelif gerekçelerle tepkili olan eski vesayet odaklarının mücadelesinin yanı sıra, yeni vesayet odağı olarak belirmeye başlayan ve yıllar sonra gerçekleşecek 15 Temmuz darbe girişiminin müsebbibi olan Fetullahçı Terör Örgütü (Fetö) unsurlarının sahne aldığı yeni bir döneme girilmiştir.

Bu yeni dönemde, Türk demokrasisinin krizlere yönelik algı ve duyarlılığındaki değişime paralel olarak, zamanın ruhuna uygun düşecek yeni kriz araçları/alanları/odakları devreye sokulmuştur. Esasında olağan demokratik düzenin işleyişini hedef alan bu yeni kriz üretme mekanizmalarının söylemsel altyapısı AK Parti'nin ikinci döneminde oluşturulmuştur. Bu yıllarda sivil siyasal iktidarın gündelik yaşam ilişkilerine dek uzandığı iddia edilen despotizmine atıfla kullanılan 'mahalle baskısı' kavramı, neredeyse alternatif bir çatışma alanı haline gelmiş/getirilmiş olan 'yaşam tarzları' tartışması, dış politik yönelimlerdeki farklılaşmayı tanımlamak üzere tedavüle sokulan 'eksen kayması' nitelendirmesi ve benzeri birçok söylemsel araç devreye sokulmuş; sivil siyasal iktidara yönelik suçlamalar en azından retorik düzeyinde ciddi bir değişim geçirmiştir. Bu retorik, özellikle Cumhurbaşkanı seçimlerinin yapıldığı 2007 yılından 12 Eylül 2010 yılında gerçekleşen halk oylamasına kadar geçen sürede oldukça etkili olmuş ve giderek istikrarlı bir işleyişe kavuşan demokrasinin yeni kriz alanlarıyla tanışmasına yol açmıştır.

Kendisine toplumsal bir taban ve aşinalık kazandırılan söylemsel nitelikli bu kriz alanları, AK Parti'nin üçüncü dönemiyle birlikte siyasal gündemin öncelikli konularından biri haline gelmiştir. Siyasal iktidarı açıkça hedef alan kriz üretme doğrultusundaki gayretler, yalnızca toplumdaki etnik, dinsel, mezhepsel ve ideolojik farklılıkların kaşınmasına yönelik retorik araçların kullanımıyla sınırlı kalmamış; Taksim Gezi Parkı vesilesiyle başla- 
yan ve kısa zamanda tüm Türkiye geneline yayılan olayların da gösterdiği üzere, kitlesel nitelikli kalkışmalara kadar varmıştır. Gezi olaylarını, Türk siyasal ve toplumsal mücadeleler tarihi bakımından gerek ortaya çıkışı gerek içeriği gerekse kapsamı ve aktörleri açısından bütünüyle 'yeni' olarak tanımlamak mümkündür. "AK Parti iktidarına yönelik olarak yaratılan korku ve öfkenin bir araya getirdiği anonim bir ruh halinin" (Stratejik Düşünce Enstitüsü, 2013, s. 13) kitlesel dışavurumu şeklinde özetlenebilecek olan Gezi olaylarının bilim adamları ve bağımsız araştırmacılar tarafından muhtelif yönleriyle değerlendirilmesinin büyük önem taşıdığı açıktır. Ancak bu yazınının sınırlılıkları, ister doğal yollarla başlamış olsun, ister planlı bir şekilde başlatılmış olsun, Gezi olaylarının bir yanıyla eski muktedirlerin diğer yanıyla ise giderek belirginleşmeye başlayan yeni vesayet odağının (Fetö) amaçlarına hizmet etmek üzere nasıl kullanıldığını vurgulamakla yetinmeyi zorunlu kılmaktadır. Gezi olayları etrafında oluşan/oluşturulan enerji, eski ve yeni vesayet odaklarının marifetiyle bir çeşit hükümet krizine dönüştürülmüş ve adeta konvansiyonel müdahale araçlarının boşa çıkarılmasından ötürü gerçekleştirilemeyen 'iktidar değişiminin' gecikmeli olarak ve siviller eliyle yapılmasına çalışılmıştır. Hatta bu gayretler kısmen ve kısa süreli de olsa başarılı olmuş ve 'acaba bir iktidar boşluğu mu oluşuyor' sorusu bazı zihinlerde canlanmaya başlamıştır.

Esasında zihinlerde canlanmaya başlayan bu soru, henüz terör örgütü vasfı bütünüyle ve tüm açıklığıyla ortaya çıkmamış olan Fetöcü unsurların bizatihi oluşturduğu rüşvet, yolsuzluk, tehdit ve şantaj içerikli gündemlerle meşgul edilen kamuoyunun sivil iktidara yönelik algısını şekillendirmek üzere kullanılan manipülatif bir araca dönüştürülmüştür. Devletin bürokratik aygıtını ele geçirerek onu içten içe dönüştürmeyi hedefleyen Fetöcü unsurlar, özellikle oluşturdukları suç örgütünün ihtiyaç duyduğu insan ve finans kaynağını sağlamak bakımından büyük bir önem taşıyan dershanelerin kapatılması kararı ile bu karar uyarınca gelişen dönemde, siyasal iktidarın ülkeyi yönetme kapasitesini kaybettiğini ve yozlaştığını öne süren yoğun bir propaganda sürecini işletmiştir. Genel kamuoyunun Fetö yapılanmasının gerçek yüzüyle tanışmasının da başlangıcını oluşturan bu süreç, Gezi olayları bağlamında ortaya çıkan duyarlılığı ve sonrasında gelişen şiddet olayların kendi amaçları doğrultusunda istismar etmekten, devlet sırrı niteliğindeki bilgi ve belgeleri ifşa etmeye dek uzanan geniş bir alanda işlevsel olmuştur. 
Ancak bu süreç yalnızca genel kamuoyunu etkilemeye dönük propagandif bir düzlemde yürütülmemiş, aynı zamanda doğrudan doğruya siyasal iktidarı hedef alan yargısal tasarruflarla da beslenmiştir. Hükümet üyesi bazı isimlerin de içinde bulunduğu yolsuzluk ve rüşvet iddialarını incelemek maksadıyla 17 ve 25 Aralık 2013 tarihlerinde başlatılan soruşturmalar, "bürokrasi içinde örgütlenmiş hükümeti devirmeye kararlı bir paralel yapı" (Demirel, 2015, s. 109) olduğu gerçeğinin anlaşılmasına ve bu yapıya yönelik mücadelenin öncelikli bir devlet politikası haline gelmesine zemin hazırlamıştır. Zira 17/25 Aralık soruşturmaları, soruşturma içeriklerinin doğru ya da yanlışlığından bağımsız olarak, yargı bürokrasisini kontrol eden Fetöcü unsurların ne denli etkin bir güç haline dönüştüklerini ve bu gücü de kendilerini hiçbir ahlaki ya da hukuksal kaygı ile sınırlandırmaksızın kullanabildiklerini ortaya koymuştur. Soruşturma kapsamında yasal ya da yasadışı olarak temin edilen ses kayıtları kamuoyuna sıdırılmış ve adeta siyasal iktidarı devirmeye dönük aleni bir yargısal darbe süreci başlatılmıştır. Hükümetin bu sürece yönelik olarak geliştirdiği reaksiyon ve aldığı tedbirlerin yanı sıra, 17/25 Aralık soruşturmalarının gölgesi altında gerçekleşen 30 Mart 2014 yerel seçimleri de, halkın yargı güdümlü darbe girişimi ile oluşturulmak istenen yönetim krizine geçit vermediğini ve devlet içindeki Fetöcü yapılanmaya karşı çıktığını gösteren bir sonuçla neticelenmiştir.

Bütün bu gelişmeler, her ne kadar büyük bir yol kat edilmiş olsa bile, Türkiye'nin demokratikleşme-sivilleşme sürecinin henüz tamamlanmadığ1nı ve orta-büyük ölçekli krizlere açık durumda olduğunu net bir şekilde ortaya koymuştur. Nitekim Türk demokrasisinin kriz algisında ve kriz odaklarına yönelik duyarlılığında ciddi değişimlerin gerçekleştiği ve konvansiyonel nitelikli askeri darbeler ve/veya darbe teşebbüslerinin artık ihtimal dışı görülmeye başlandığı bir dönemde, Türkiye yeniden ve tarihinin en şedit ve kanlı darbe girişimiyle karşı karşıya kalmıştır.

\section{Vesayetin Yeni Bir Türü Olarak 15 Temmuz Fetö Darbe Girişimi ve Sonuçlan}

Vesayetçi paradigmanın tasfiyesine dönük mücadele süreci, 15 Temmuz 2016 gününün akşam saatlerinde başlayan darbe girişimiyle birlikte yeni bir döneme girmiştir. Türkiye' deki yerleşik vesayetçi geleneğin ürettiği demokrasiye müdahale araçlarından farklı olarak, bu darbe girişimi, toplumsal 
alanda örgütlendiği, kültürel ve eğitimsel nitelikli işlerle iştigal ettiği ve dahası insanlığın baki kurtuluşu için çalıştığı varsayılan ya da en azından öyle olduğunu iddia eden bir 'sivil toplum örgütünden' gelmiştir. Kendisini her ne kadar salt manevi yönelimli bir iyilik hareketi olarak sunsa da, bu 'sivil toplum örgütü'nün gerçek amacı hep bir sır olarak kalmış, bu yapının niyetlerinden şüphe ya da sual edenler korku, tehdit ve şantajla bastırılmıştır. Ancak özellikle 2013 yılında yaşanan dershane tartışması ve ardından 17/25 Aralık soruşturmalarıyla devam eden süreç, bu yapının toplumsal alanda örgütlenmiş hayırhah bir sivil toplum örgütü olmadığını, tam aksine devletin bürokratik aygitını ele geçirerek onu içten içe dönüştürmeyi hedefleyen bir suç örgütü olduğunu açığa çıkarmıştır (Kızılkaya, 2014, s. 55). Esasında bu yapının gerçek kimliğini açığa çıkaran gelişmelerin tarihi 2013 yılının da öncesine uzanmaktadır. Kürt sorununun çözümüne yönelik arayışlar kapsamında gerçekleştirilen Oslo görüşmelerinin kamuoyuna ifşa edilmesi ve 7 Şubat 2012 tarihinde yaşanan MiT krizi, Fetullahçı yapılanmanın devlet içinde ne denli etkin bir konuma ulaştığının ve kendi özel gündemine göre hareket ettiğinin ilk sinyallerini vermiştir. Akabinde yaşanan süreçte ise, Gezi olaylarının siyasal iktidar aleyhine istismar edilmesi, MiT tırlarının durdurulması, Türkiye'nin Suriye'deki terörist gruplara destek vermekle suçlanması, özel hayatın gizliliğini ihlal eden gayrimeşru yöntemler üzerinden sivil siyaset alanının dizayn edilmesi yönünde bir dizi alg1 operasyonu gerçekleştirilmiştir (Çetin, 2015, s. 78).

Bütün bu gelişmelerin yanı sıra, dershane sürecinde yaşanan tartışmalar ve 17/25 Aralık soruşturmaları Fetullahçı yapılanmanın suç örgütü niteliğinin geniş toplumsal kesimler tarafından anlaşılması bakımından önemli bir dönüm noktası olmuştur. Bu suç örgütüne mensup olan insanların devlet aygıtının en kritik pozisyonlarında bulunması ve siyasal iktidara değil de, kendi özel gündemine tabi olarak çalışan özerk bir grup ve hatta çete gibi hareket etmesi, Fetullahçı yapılanmanın Türkiye'nin barış ve güvenliğini tehdit eden bir istikrarsızlık kaynağı/odağı haline geldiğini göstermiştir. Nitekim 15 Temmuz 2016 tarihinde gerçekleşen darbe girişimi, bu yapının "askeri vesayet ile demokrasi üzerinde tahakküm kurmayı hedefleyen ve bu amaçla sistematik şekilde organize olan" (Hotar, 2020, s. 17) bir terör örgütü olduğunu ortaya koymuştur. 15 Temmuz darbe girişimi, her ne kadar konvansiyonel nitelikli bir askeri müdahale biçiminde temayüz etse de, gerek ordu içindeki emir komuta zincirinin dişında gerçekleşmiş olması, 
gerekse dinsel kamuflajlı bir örgüt tarafından yapılmış olması nedeniyle yeni bir tür kalkışma (Uzun, 2016, s. 1) olarak kayıtlara geçmiştir.

Türkiye, demokrasiyi savunmak üzere bir araya gelen iktidar ve muhalefet ile halkın topyekûn direnişi sayesinde bu darbe girişimini yirmi dört saatten daha kısa bir süre içinde başarısızlığa uğratmış ve darbecilerin teslim olmasını sağlamıştır (Anadolu Ajansı, 2016, s. 7-8). Siyasal iktidar, 15 Temmuz darbe girişimi bertaraf edildikten hemen sonra, ülkeyi resmi ve sivil alanda örgütlenmiş olan Fetöcü unsurlardan arındırmayı hedefleyen bir süreç başlatmıştır. Söz konusu süreç kapsamında, ilk olarak olağanüstü hal (OHAL) ilan edilmiş ve Fetö aidiyeti, iltisakı veya irtibatı belirlenen kişi, kurum, kuruluş, vakıf ve derneklere yönelik operasyonlar gerçekleştirilmiştir (Gülener ve Erciyas, 2016, s. 19). Dört yılı aşkın süredir devam eden bu arındırma sürecinin bundan sonraki yıllarda da süreceği aşikardır. Tüm örgütlenmesini gizlilik esasına dayalı olarak şekillendiren Fetö yapılanmasının neredeyse resmi ve özel nitelikli bütün yaşam alanlarına sirayet etmiş olan etkinliğini ve nüfuzunu tespit ve tasfiye etmenin güçlüğü bir yana, örgütün Türkiye dışındaki varlığı ve bazı ülkeler tarafından himaye edilmesi de sürecin uzamasına neden olmaktadır.

15 Temmuz darbe girişimi, her ne kadar Türkiye'deki yerleşik vesayetçi geleneğin dişında gerçekleşmiş olsa da, ülkenin genel siyasal kültürü ile geçmişinden beslenen militarist bir arka plan içinde gelişip serpilmiştir. Bu durum, vesayetçi paradigmanın tasfiyesine dönük çabaların, yalnızca konvansiyonel nitelikli müdahale araçlarıyla sınırlı tutulmaması gerektiğini ortaya koyduğu gibi, Türk demokrasisinin eski ya da yeni tarz krizlerden etkilenmemesi için özgürlükçü ve reformcu niteliğini sürdürmesi gerektiğini de göstermiştir. Söz konusu gereklilikler, 15 Temmuz darbe girişiminin faillerine dönük olarak yürütülen mücadele kadar önemli bir başka gerçeğe işaret etmektedir. Bu gerçeği, Alkan'ın (2018, s. 267-268) tespitiyle, 15 Temmuz darbe girişiminin üç önemli sonucu olarak da değerlendirmek mümkündür. Sonuçlardan birincisi, fırsat eşitliğine dayanan ve liyakati esas alan bir kamu hizmeti anlayışının yapılandırılması ihtiyacının belirgin hale gelmiş olmasıdır. İkincisi, devlet-sivil toplum ilişkisinin kuramsal ve kurumsal boyutlarıyla birlikte yeniden tanımlanması ihtiyacının net bir şekilde anlaşılmış olmasıdır. Üçüncü ve son önemli sonuç ise, toplumsal meşruiyet kalıplarının oluşmasında merkezi bir rol oynayan dinsel değer ve kavramla- 
rın, belirli kişi ve grupların tekelinden ve tasallutundan kurtarılması ihtiyacının ortaya çıkmış olmasıdır.

\section{Sonuç}

Osmanlı geçmişinden devralınan modernleşme anlayışı/çizgisinin temel karakteristik özelliklerinden biri olan militarizm, aynı zamanda cumhuriyet dönemi Türkiye'sinin siyasal tarihini de şekillendiren en önemli unsurlardan biri olmuştur ve olmaya da devam etmektedir. 1945'ten beri süregelen demokrasi deneyimi, militarist zihniyet ve geleneğin taşıyıcısı konumunda bulunan ve kendisini devlet aygıtıyla özdeşleştiren vesayetçi azınlık ile söz konusu azınlığa karşı direnen ve geniş halk kitlelerinden oluşan sessiz çoğunluk arasındaki mücadelelerin seyrini yansıtmaktadır. Dolayısıyla Türkiye'nin kısa süreli demokrasi tarihini, Osmanlı-Türk modernleşmesine koşut bir biçimde gelişen militarist gelenek ile bu geleneğe dayalı olarak şekillenmiş olan kavram, aktör, yapı ve pratiklerden bağımsız olarak değerlendirmek mümkün değildir.

Cumhuriyetin kuruluş süreci ile sonrasında yaşanan tek parti döneminde, militarizm, Atatürkçü milliyetçilik ile birlikte, resmi ideolojinin bizatihi kendisi olarak temayüz etmiştir. Demokratik süreç ve mekanizmaların işletilemediği, tek parti yönetiminin mutlak egemenliğinin olduğu ve her türlü muhalefetin bastırıldığ 1 bu dönemde, vesayetçi paradigma devlet düzeyinde kurumsallaşmış ve adeta sonraki yılların da kurucu referans değeri olarak işlev görmüştür. Nitekim Türkiye'nin demokrasiye geçtiği ve halkın özgür iradesiyle iktidarların belirlenmeye başladığı 1945 yılı ve sonrasında meydana gelen askeri müdahalelerin tamamı, kendisini devletle özdeş ve hatta onun sahibi olarak gören militarist bir zihniyet/kadro tarafından gerçekleştirilmiştir. 27 Mayıs 1960 Askeri Darbesi ile başlayan demokrasiye müdahale geleneği, kısa aralıklarla tekrar eden yeni darbeler/darbe teşebbüsleri ve muhtıralar vasıtasıyla vesayetçi paradigmanın temelini oluşturan militarist ideolojiye süreklilik kazandırmıştır. Tabii demokratik işleyişin bütünüyle askıya alınmasına neden olan ya da meşru siyasal iktidara kontrollü/gözetim altında bir tasarruf alanı bırakan militarist ideoloji, yalnızca askeri zeminde gelişen ve ona yaslanan bir çerçeve içinde değil, aynı zamanda kendisine eşlik eden 'sivil' dinamiklerden de beslenmiştir. Örneğin 28 Şubat postmodern darbe sürecinde, militarist ideolojinin görünürlüğünü 
sağlayan temel aktörler arasında askerler kadar, 'sivil' kişi ve kurumlar da yer almış; sivil-siyasal alanı birlikte dizayn etmişlerdir.

Ancak militarist ideolojinin siyaset üzerindeki hegemonik konumunu içselleştiren ve ona aleni şekilde destek veren bu 'sivil' unsurların statükodan beslenen seçkinci zümrelerle sınırlı olduğunu belirtmek gerekir. Olağan demokratik süreçlere dönük müdahaleler, geniş halk kitleleri arasında karşılık bulamadığı gibi, kendisini sürekli kılacak mekanizmaları da üretememiş ve iktidarı, her seferinde halkın demokratik iradesini yansıtan aktörlere bırakmak zorunda kalmıştır. 27 Mayıs'tan 28 Şubat post-modern darbesine dek uzanan tüm müdahale süreçleri, vesayetçi azınlığın tahakkümcü otoritesinin sessiz çoğunluğun meşru iradesi karşısındaki yenilgisinin örnekleri ile doludur. Müdahale dönemlerinin akabinde yapılan seçimler, vesayetçi azınlığın 'sakıncalı' bulduğu siyasal partilere dönük teveccühün arttığını ve halkın bu partileri ya tek başına ya da iktidar ortağı olarak yönetime taşıdığını ortaya koymuştur.

28 Şubat müdahalesinin biçimlendirdiği bir siyasal iklim içinde gerçekleşen 3 Kasım 2002 seçimlerinde AK Parti'nin tek başına iktidara gelmesini de bu minvalde değerlendirmek mümkündür. AK Parti iktidarının 2002-2007 yılları arasını kapsayan ilk döneminde, sivil siyaset alanının genişlemesini sağlayan demokratik reformlar gerçekleştirilmiş, vesayetçi paradigmaya dayalı olarak şekillenen statükonun aşılmasına dönük ciddi bir mücadele süreci başlatılmıştır. Bu süreç, 2007 yılında yaşanan ve AK Partili bir ismin cumhurbaşkanı olarak seçilmesini engellemeye dönük olarak hazırlanan 27 Nisan e-muhtırası ile birlikte yeni bir safhaya girmiştir. AK Parti'nin ikinci döneminin (2007-2011) de başlangıcını oluşturan bu safhada, geçmişte gerçekleşen askeri darbeler ve darbe teşebbüslerinin yargılanması da dahil olmak üzere, klasik vesayetçi paradigmanın tasfiyesini amaçlayan ve bunu büyük oranda başaran bir mücadele sürdürülmüştür.

Bu mücadelelerin bir sonucu olarak, Türk demokrasisinin neredeyse askeri müdahale ile eş anlamlı olarak kullanageldiği kriz algısında ve kriz odaklarına yönelik duyarlılık düzeyinde belirgin bir değişim gerçekleşmiş ve vesayetçi yapıların demokratik sisteme dönük müdahale yeteneğini/kapasitesini kaybettiği yönünde bir kabul oluşmaya başlamıştır. Ancak AK Parti'nin 2011 ile 2015 yılları arasını kapsayan üçüncü döneminde ve sonrasında yaşanan süreç, bu kabulün yanlış bir temele dayandığını ortaya koymuştur. Söz konusu süreçte vuku bulan gelişmeler, Türkiye'nin aşina 
olduğu klasik vesayetçi paradigmanın dişında beliren ve yeni bir tür vesayet odağı olan Fetöcü yapılanmayla tanışmasına sebebiyet vermiştir. MITT krizi, dershane tartışmaları ve 17/25 Aralık soruşturmaları kapsamında yaşanan hadiseler, uzun yıllar boyunca kendisini sivil toplum alanında örgütlenmiş hayırhah bir oluşum olarak sunan/sunabilen bu yapının, gerçekte devlet bürokrasisinin içine sızan ve oradan devşirdiği güçle siyasal iktidarı devirmeye çalışan bir terör örgütü olduğunu ortaya çıkarmıştır. 15 Temmuz 2016 tarihinde gerçekleşen ve Cumhuriyet tarihinin en kanlı teşebbüsü olarak kayıtlara geçen darbe girişimi ise, bu durumu hiçbir şüpheye mahal bırakmayacak şekilde tescillemiştir.

Siyasal iktidarın kararlı duruşu, muhalefet partilerinin açk desteği ve halkın topyekûn direnişi sayesinde bertaraf edilen 15 Temmuz darbe girişimi, Türkiye'de konvansiyonel nitelikli askeri müdahalelerin artık yaşanmayacağı yönündeki kamuoyu algısının yanlışlığını ortaya koyduğu gibi, vesayetçi paradigma ile mücadelenin yalnızca klasik militarist yapılarla sınırlı tutulmaması ve sivil siyaset alanının yeniden ve özgürlükçü bir temelde yapılandırılması gerektiğini de göstermiştir. 


\title{
EXTENDED ABSTRACT
}

\section{A Periodic Evaluation On The Elimination of Tutelary Paradigm in Turkey: 2002-2016.}

\author{
Ahmet Kizılkaya \\ Ministry of National Education
}

The period from 1945, when Turkey adopted the multiple party system, to date, includes almost unique examples not only in terms of its political history, but also in terms of world political history. However, this given exemplary situation of the Turkish political history does not indicate positive content including historical heritage which flatters national pride of Turkey or addressing to establishment a precedent improvement/ development/democratization model, it points out the anti-democratic past which tutelage paradigms castrated. Because, this history, has produced a militarist climate shaped by frequent conventional military coups and / or coup attempts. Of course, the actors and mechanisms that produced this climate have always failed in the face of the silent but stable resistance of the wide social segments, and they have failed to ensure the sustainability of the tutelage structures they have established despite the will of the people. From this point of view, it is possible to read the history of Turkey's democracy as the history of dialectical struggle between tutelary minority and the silent majority. This struggle, which covered almost the entire second half of the twentieth century and generally would be continued against to the silent majority, has begun to follow a different course with the first years of the twenty-first century has begun to come to the forefront; the status quo/permanent settlement formed by elitist groups who see themselves as the real owners of the country has weakened, actors and mechanisms that reflect the democratic will of the people have come to the fore. In this process, military coups and coup attempts staged in the past started to be questioned and so be tried, the areas of freedom were broadened through political and legal regulations, and all living spaces, especially printed and visual media, were diversified to be reflect the pluralism of the country. Despite the all these positive changes and strong development momentum that the country catched up both outside and inside, the marks of Turkey's inherited 
negative inheritance from the previous century has continued its existence in explicit or implicit manner. In fact, the tutelage paradigms which has been going on for decades and has been institutionalized over time, has produced a contentful "democracy intervention literature" that can renew itself under any condition and circumstance. Turkey's short time democracy history is full of many political, military, bureaucratic and jurisprudential coup or coup attempts, which were made or were failed by operation of this literature. However, as stated above, these coup attempts have been obviated with the democratic reflexes that the people maintained medium-long term and prudential stance, and the country's trajectory has been gotten irreversibly back to the course of democracy (Kızllkaya, 2014, s. 54-55).

The collective resistance, which is put up against to the coup attempt of 15 July 2016 which is the last and the most severe example of the tradition of intervention in democracy that started with the military coup of 27 May 1960 and which includes all social segments, has clearly demonstrated how deeply rooted and how internalized of both this reflex and the awareness of protecting democracy, because of its currentness and spontaneous nature. This resistance, which is rare in the history of the world, has shown in a concrete way that evet at all cost, the people, in the most general statement, will not renounce democracy and democratic gains, and will not give their will in to the tutelage centers. Both the 15 July coup attempt which keeps itself up-to-date in terms of its political, social and psychological effects and consequences, and the collective resistance standing against to the attempt have made explicit not only the clarification of Turkish democracy from the centers and tools, which have come from the past and manifested themselves on all occasions, but also the reconstruction of Turkish democracy. In fact, after July 15, Turkey has entered into a process of fundamental change which includes the management structure; has adopted to the Presidential System of Government regarded as a version of the presidential system unique to Turkey and abandoned classic parliamentary system. This system, which has been come into force since the second half of 2018 and is still under restructuring process, has been shaped as a result of a quests for the elimination of the tutelage paradigm, independently of the debates, which are related whether Turkish democracy can correct its problematic / tutelary nature or whether it can permanently and structurally remove the potential coups, memorandums and similar crises that it can produce, and 
the criticisms which are directed to the management model and the implementation process.

In this study, it is aimed to examine the tutelary interventions and purging struggles against to them, which also include coup attempt staged on 15 July 2016 and its consequences, and experienced during the Justice and Development Party's rule(s) that have started since the election of 3 November 2002 and continued uninterruptedly until today. In line with this purpose, the process that took place during the first decade of the AK Party and aimed at the purging of the tutelage paradigm was analyzed; then, the changing crisis perception of Turkish democracy also was examined. In the successive section, the parallel state structure (FETÖ/PYD), which emerges as a new type of tutelage, was discussed in the context of the July 15 coup attempt and its consequences. Finally, a general evaluation of the struggles for the purging of the tutelage paradigm, covering the years between 2002 and 2016, was carried out.

\section{Kaynakça / References}

Alkan, H. (2016). 15 Temmuz'u Anlamak: Parametreler ve Sonuçlar. Bilig, 79: 253272.

Anadolu Ajansı (2016). Dakika dakika FETÖ'nün darbe girişimi: 15-20 Temmuz 2016. İstanbul: $\quad$ AA $\quad$ Yayınları. $\quad$ 03.12.2020 tarihinde https://www.aa.com.tr/uploads/TempUserFiles/pdf\%2Ffeto_darbe girisim i.pdf adresinden erişildi.

Bayramoğlu, A. (2013). Asker ve siyaset. (A. İnsel ve A. Bayramoğlu, Der.). Bir zümre, bir parti: Türkiye'de ordu. İstanbul: Birikim Yayınları, 37-74.

Çetin, Ü. (2015). Toplum mühendisliğinden siyaset mühendisliğine bir durak. Liberal Düşünce, 77, 75-87.

Demirel, T. (2015). Liberal düşünce topluluğu çevresindeki farklılaşmalar üzerine. Liberal Düşünce, 20 (77), 107-123.

Gülener,S. ve Erciyas, S. (2016). Dünyada arındırma uygulamaları ve türkiye'de devletin Fetö'den arındırılması. SETA Analiz, 179.

Hotar, N. (2020). Türk demokrasisindeki kesintiler ve 15 temmuz kalkışmasının hedefindeki Türkiye. Çă̆daş Türkiye Tarihi Araştırmalan Dergisi, 10(Özel Say1), 7-29.

Bu Defa İşi Silahsız Kuvvetler Halletsin. (20 Aralık 1996). Hürriyet Gazetesi, 20.12.1996. 
Kızılkaya, A. (2013). Türk demokrasisinin değişen kriz algısı. Kamu'da Sosyal Politika Dergisi, 25.

Kızılkaya, A. (2014). Eğitim alanından devşirilen vesayet. Stratejik Düşünce Dergisi, 60, 54-56.

Mahçupyan, E. (2013). Bir mikro ideoloji olarak militarizm: Zihniyet, özne ve etik meseleleri üzerine bir not. (A. İnsel ve A. Bayramoğlu, Der.). Bir zümre, bir parti: Türkiye'de ordu. İstanbul: Birikim Yayınları, 75-84.

Laiklik Uyarısı. (17 Ekim 1996). Milliyet Gazetesi, 17.10.1996.

Ordu Rahatsız. (13 Aralık 1996). Sabah Gazetesi, 13.12.1996.

Stratejik Düşünce Enstitüsü (2013). Taksim Gezi Parkı eylemleri raporu. Ankara: SDE Yayınları.

Şahin, B. (2006). Türkiye'nin Avrupa Birliği uyum süreci bağlamında Kürt Sorunu: Açılımlar ve sinırlar. (A. Kaya ve T. Tarhanlı, Der.). Türkiye'de çoğunluk ve azınlık politikaları: $A B$ sürecinde yurttaşlık tartışmaları, İstanbul: TESEV Yayınlarl, 122-159.

Şahin, B. (2013). Farklılık, hoşgörü ve Ak Parti İktidarı: Gezi Parkı sürecinin düşündürdükleri. Liberal Düşünce, 18(71), 161-169.

Uzun, C.D. (2016). 15 Temmuz Darbe girişimi sonrası olağanüstü hal ilanı ve sonuçları. SETA Perspektif, 138.

\section{Kaynakça Bilgisi / Citation Information}

Kızılkaya, A. (2020). Türkiye'de vesayetçi paradigmanın tasfiyesi üzerine dönemsel bir değerlendirme: 2002-2016. OPUS-Uluslararası Toplum Araştırmaları Dergisi, 16(32), 4966-4986. DOI: 10.26466/opus.835844 